\title{
Bilateral Malphigian bulge or pseudohernia simulating inguinal hernias in a case of spontaneous descent of bilateral undescended testis
}

\author{
Ramnik V Patel, ${ }^{1,2}$ Dhaval Govani, ${ }^{3}$ Rasila Patel, ${ }^{4}$ Sudhir G Mehta ${ }^{5}$
}

${ }^{1}$ Department of Paediatric Urology, University College London Hospitals NHS

Foundation Trust, London, UK ${ }^{2}$ Department of Paediatric Urology, Great Ormond Street Children Hospital NHS Trust, London, UK

${ }^{3}$ Birmingham Medical School, Birmingham, UK

${ }^{4}$ Department of Contemporary Alternative Paediatrics, PGICHR, Rajkot, Gujarat, India ${ }^{5}$ Department of Surgery, MPSMC and GGGH, Jamnagar Gujarat, India

\section{Correspondence to}

Ramnik V Patel,

ramnik@doctors.org.uk
To cite: Patel RV, Govani $D$, Patel R, et al. BMJ Case Rep Published online: [please include Day Month Year] doi:10.1136/bcr-2013200569

\section{DESCRIPTION}

Term infant was noted to have bilateral undescended testes at birth. At 6 weeks parents show bilateral swellings in lower abdomen during the infantile colic period. General practitioner and paediatrician have confirmed herniae. During examination both inguinal undescended testes were palpable in the groin with hypoplastic scrotum but no definite inguinal hernia could be seen. Bilateral Malphigian bulge or pseudohernias were evident on the right side being more prominent than the left side. Parents were requested to take photographs during peak of infantile colic. The photographs further confirmed the findings and the bulges were bilateral, diffuse in a large area, and well above the inguinal canal without any fullness or swelling of the inguinal canal or scrotum (figure 1). At 7 months of age both testes have descended down into the scrotum spontaneously and had no evidence of hernia. At 10 years he is well and both testes remain at the bottom of the scrotum. Inguinal herniae and undescended testes are the most common paediatric surgical conditions having important paradoxical clinical management implications at young age. Inguinal hernias in infants may not be evident during visit, thickening of cord and silk sign is not available and the diagnostic confusion could be real. ${ }^{1}$ Examination should confirm the diagnosis whenever possible, although clear evidence from parents or health workers can be accepted. ${ }^{2}$ Parental photographic confirmation of the hernia may be helpful and accurate. ${ }^{3}$ Inguinal hernias need surgical repair while undescended testes demand to wait for the postnatal testosterone surge for spontaneous descent at least up to the age of 6 months. Pseudohernia or Malphigian bulges are quite often seen physiologically at the extremes of ages in young infants and very elderly due to weak muscles of the abdominal wall and poor tone while it can be seen in post-traumatic or postoperative injury to nerves, postinfective conditions or metabolic diabetic neuropathy. ${ }^{4-6}$ Until recently, surgical dogma dictated that every hernia be repaired because of the risk of complications. This approach, however, has been questioned, leading to a large multiinstitutional study sponsored by the American College of Surgeons comparing watchful waiting to prophylactic repair of asymptomatic inguinal hernias. ${ }^{7}$ Before this study, very little was actually known about the natural history of an asymptomatic hernia left untreated, although studies indicate that the incidence of incarceration is actually quite low. ${ }^{8}$ Neither open nor laparoscopic approach improves the bulge caused by abdominal muscle atrophy. The option of a muscular and prosthetic reconstruction provides better clinical and cosmetic results. ${ }^{9}$

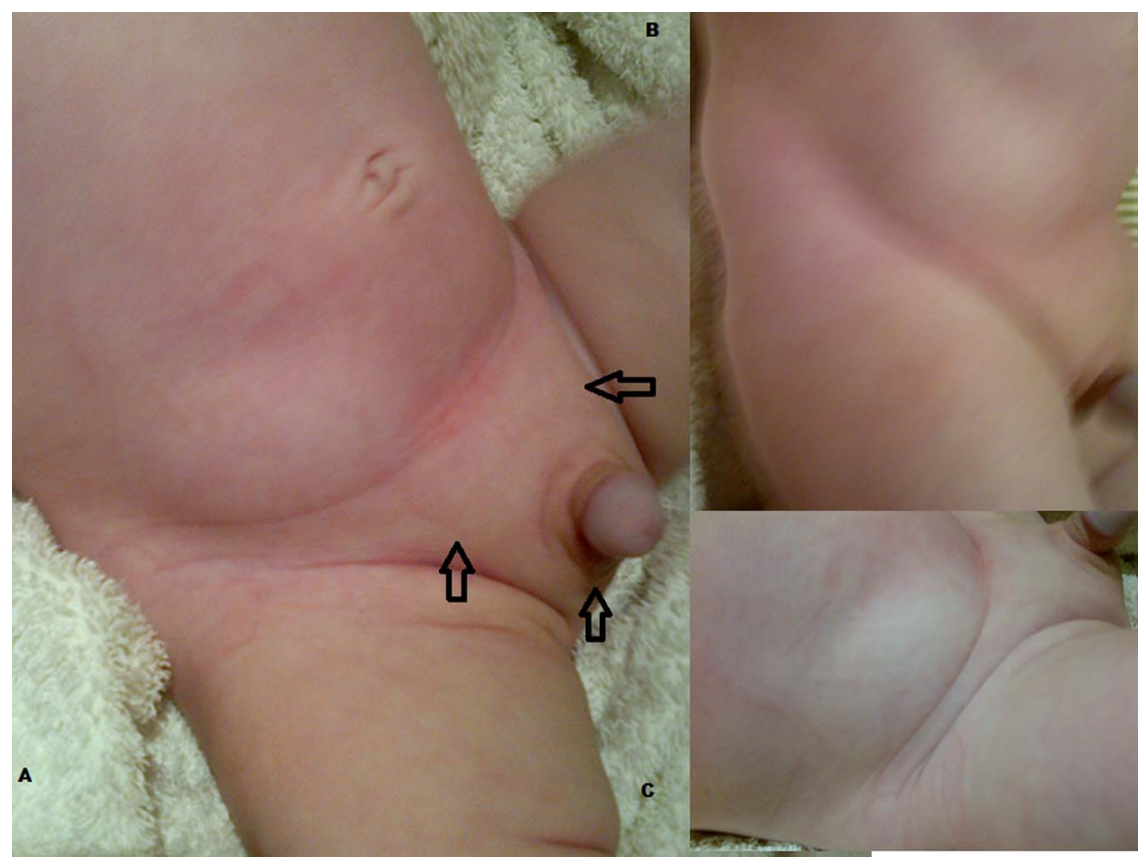

Figure 1 Clinical photograph showing diffused swelling well above and lateral to the inguinal crease. 


\section{Learning points}

- Combination of undescended testes and inguinal hernia is common but accurate diagnosis is required especially in bilateral cases as inguinal herniae implies relatively urgent operative repair while the undescended testes dictates conservative management more in bilateral cases then unilateral ones.

- Infantile colic period could be really very stressful for the baby and the parents alike and if someone raises the possibility of inguinal hernia and its potential complications and risks involved; it may be a very difficult situation to convince the parents other way round and it avoids potential risk to vas deference and vessels.

- Digital photographs by parents during acute phase of infantile colic are very helpful, simple, easily available, accurate, fast and reliable method of diagnosis. The inguinal hernia is at or below the inguinal skin crease running obliquely to groin or scrotum.

Contributors All authors have actively participated in the management of this patent and in the preparation, editing, appraising and finalisation of the manuscript.
Competing interests None.

Patient consent Obtained.

Provenance and peer review Not commissioned; externally peer reviewed.

\section{REFERENCES}

1 Pandey A, Rawat J, Pandey J, et al. Abdominal wall ectopic testis mimicking spigelian hernia. J Pediatr Surg 2011;46:415-16.

2 MacKinnon AE. Herniae and hydroceles. In: Burge DM, Griffiths DM, Steinbrecher HA, Wheeler RA, eds. Paediatric surgery. London: Hodder Arnold, 2005, 301-10.

3 Kawaguchi AL, Shaul DB. Inguinal hernias can be accurately diagnosed using the parent's digital photographs when the physical examination is non-diagnostic. J Pediatr Surg 2009;44:2327-9.

4 Durham-Hall A, Wallis S, Butt I, et al. Abdominal wall pseudohernia following video-assisted thoracoscopy and pleural biopsy. Hernia 2008;13:93-5.

5 Oliveira PD, dos Santos Filho PV, de Menezes Ettinger JE, et al. Abdominal-wall postherpetic pseudohernia. Hernia 2006;10:364-6.

6 Chiu HK, Trence DL. Diabetic neuropathy, the great masquerader: truncal neuropathy manifesting as abdominal pseudohernia. Endocr Pract 2006;12:281-3.

7 Fitzgibbons RJ Jr, Giobbie-Hurder A, Gibbs JO, et al. Watchful waiting vs. repair of inguinal hernia in minimally symptomatic men; a randomized clinical trial. JAMA 2006;295:285-92.

8 Rege RV. Invited commentary: incidence of occult inguinal and spigelian hernias during laparoscopy for other reasons. Surgery 2006;140:12-13.

9 Moreno-Egea A, Sanchez-Elduayen M, Parlorio, et al. Is muscular atrophy a contraindication in laparoscopic abdominal wall defect repair? a prospective study. Am Surg 2012;78:178-84.

Copyright 2013 BMJ Publishing Group. All rights reserved. For permission to reuse any of this content visit

http://group.bmj.com/group/rights-licensing/permissions.

BMJ Case Report Fellows may re-use this article for personal use and teaching without any further permission.

Become a Fellow of BMJ Case Reports today and you can:

- Submit as many cases as you like

- Enjoy fast sympathetic peer review and rapid publication of accepted articles

- Access all the published articles

- Re-use any of the published material for personal use and teaching without further permission

For information on Institutional Fellowships contact consortiasales@bmjgroup.com

Visit casereports.bmj.com for more articles like this and to become a Fellow 